\title{
Drivers and Barriers of Environmental, Social and Governance Information in Investment Decision-Making: The Spanish Case
}

\author{
Juan Diego Paredes-Gazquez ${ }^{1}$, Laura Lazcano Benito ${ }^{2} \&$ Marta de la Cuesta González $^{1}$ \\ ${ }^{1}$ Universidad Nacional de Educación a Distancia, Spain \\ ${ }^{2}$ Universidad Pontificia de Comillas, Spain \\ Correspondence: Juan Diego Paredes-Gazquez, Facultad de Ciencias Económicas y Empresariales, Universidad \\ Nacional de Educación a distancia, Despacho 3.32, Calle Senda del Rey 11, 28040 Madrid (Spain), Spain. Tel: \\ 349-1398-6354. E-mail: juandiegoparedes@cee.uned.es
}

Received: June 27, 2014

Accepted: June 11, 2014

Online Published: August 22, 2014

doi:10.5539/ijbm.v9n9p16

URL: http://dx.doi.org/10.5539/ijbm.v9n9p16

\begin{abstract}
Socially responsible investment (SRI) and the consideration of environmental, social and governance (ESG) issues when investing has experienced tremendous growth in recent years around the world and especially in Europe. The aim of this paper is to analyse the drivers and barriers to the integration of ESG information in the financial market and why Spain has not kept pace with countries that have traditionally been leaders in SRI. For this purpose, we interviewed Spanish investors, asset managers, analysts and invested companies (in particular investor relations departments) to analyze their perceptions of ESG integration and determine the specific drivers and barriers to ESG integration in investment.
\end{abstract}

Keywords: environmental, environmental, social and governance (esg) issues, integration, management, drivers, barriers, Spain

\section{Introduction}

Although there is no consensus on the definition of socially responsible investment (SRI) (Sandberg et al., 2009; Sparkes \& Cowton, 2004), it could be considered a generic term covering any type of investment process that combines investors' financial objectives with their concerns about Environmental, Social and Governance (ESG) issues (Eurosif, 2010a). Jemel-Fornetty et al. (2011) pointed out that SRI has an ethical background, while ESG is more business oriented.

Thus, if the ESG concept is understood in a broad sense, then assets managed under ESG issues have grown dramatically. However, if this concept is understood in a narrow sense, the situation is totally different. This paper deals with ESG issues as a tool for creating value, following the Eurosif (2010a) definition of integration. Thus, integration is a part of Responsible Investment (RI), a particular area of SRI focused on bringing ESG issues into traditional financial analysis. This way, integration is part of SRI.

In recent years, SRI has grown exponentially in Europe. According to Eurosif (2012), while assets managed under SRI criteria in Europe had a value of $€ 336$ billion in 2003, this value reached $€ 4.9$ trillion in 2011; i.e. a growth of $1361.6 \%$ in 8 years. France, the United Kingdom and the Netherlands are leading countries in ESG integration, while the volume of assets managed under ESG integration criteria in Germany and Spain is not significant.

Concerning leading countries, assets managed under ESG integration criteria in France have grown spectacularly in four years, reaching $€ 1804.7$ billion in 2009 , due to le Grenelle de l'environnement regulation concerning pension fund managers (Knopf et al., 2010). Although France has become a world leader in integration in recent years, the United Kingdom has traditionally had the highest volume of assets managed under integration. The 2000 Pensions Act disclose requirement in occupational pension funds, strengthened through The Occupational Pension Schemes (Investment) Regulations 2005 has been the main driver in the United Kingdom, although the contribution of High Net Worth Individuals (HNWIS) has been also noteworthy. 
The Netherlands also has a great tradition in SRI. In the last few years, political initiatives concerning the negative screening of cluster munitions for all Dutch investors have been developed, and many pension funds have begun to provide information on their responsible investment activities in their annual reports.

On the other hand, Germany and Spain have developed small SRI markets (Eurosif, 2012). Freshfields Bruckhaus Deringer (2005) and Richardson and Preu (2011) concluded that one of the main barriers to SRI in Germany is the conservative German investor profile, since most SRI products are related to the stock market. At the same time, institutional investor regulation in Germany has made ESG integration difficult. From 2009 to 2011, German SRI has grown mainly due to Principles for Responsible Investment (PRI) signatories' investment, but the volume of investment is still small.

Although Prado-Lorenzo et al. (2008) showed evidence of some efforts to promote SRI in Spain, this is still a small investment niche (Novethic et al. 2012). Total assets managed under SRI criteria and the institutional and retail investors market are both small. Most Spaniards prefer real estate investment or simple deposits for their savings, thus resulting in small pension and investment funds, which are not as powerful as other references in Europe, i.e. Stichting Pensioenfonds ABP or The Government Pension Fund of Norway (Lozano et al., 2006).

As Capelle-Blancard and Monjon (2012) claimed, most studies have focused on the relationship between SRI and financial performance, but have provided little insight into the theoretical understanding of SRI investment. We aimed to fill this gap by analysing the drivers and barriers to ESG integration in the SRI market, looking at the Spanish case as Freshfields Bruckhaus Deringer (2005) and Richardson and Preu (2011) did for the German case. We also aimed to identify the barriers that have prevented Spain from keeping pace with the rest of Europe and the drivers that could help to develop this market in Spain.

For this purpose, we interviewed Spanish investors, asset managers, analysts and invested companies (in particular investor relations departments) to analyze their perceptions of ESG integration and determine the specific drivers and barriers to the integration of ESG information in investment. The second section of this paper presents a literature review of these drivers and barriers. In the third part, we present the methodology used and the results obtained for the Spanish case. Finally, the paper ends with the main conclusions of the study.

\section{Importance of ESG Integration in the Mainstream Market: Drivers and Barriers}

Several studies have tried to identify the main driving forces and barriers to ESG integration. The most ambitious project related to understanding the impact of ESG integration is the Sustainable Value EABIS Research Project (EABIS, 2009). The main conclusion was that the financial market knows about the potential advantages of ESG integration, but there are still too many barriers to exploit their full potential. A set of recommendations was given, such as the need for members of the financial market to make a clear commitment to ESG integration or the need to improve communication between members of the financial market.

Jemel-Fornetty et al. (2011) analyzed the barriers associated with collective convictions in the financial market when managing ESG issues. These authors found that each member develops his own way of dealing with ESG information, which in turn makes it difficult for the dominant collective belief to change. Greater coordination and more dialogue are needed for ESG integration to become a homogeneous trend. Juravle and Lewis (2008), who discussed the impediments of SRI in Europe, distinguished between institutional, organizational and individual barriers and found that the latter is a key to changing the perception of SRI.

Guyatt (2006) also analyzed the main barriers to SRI, focusing on UK investors. She found ten different barriers, among which she highlighted the separation of teams dealing with Corporate Social Responsibility issues and market focus on short term results.

If we structure the findings of Jemel-Fornetty et al. (2011), EABIS (2009), Juravle and Lewis (2008) and Guyatt (2006), we can obtain a classification of the status of ESG integration based on different groups of drivers and barriers.

\subsection{Drivers}

The main driving forces for ESG integration can be classified into three groups: market pressures, group pressures and institutional pressures.

Market pressures are external forces promoting ESG integration. Market pressures will be different for each member of the financial market. Nowadays, market pressure is mainly led by investors and analysts (Sievänen et al., 2013), and most companies have adopted a reactive position toward ESG management (Slager, 2012).

Investment companies with variable capital and investors with high purchasing power or high net worth individuals (HNWIs) are also demanding the integration of these factors in their investment decisions (Eurosif, 
2010b; UNEP FI \& WBCSD, 2010). Crifo and Forget (2013) found that, for French private equity investors, ESG issues mean mainly risk management and new market creation.

ESG integration in pension funds is leading asset managers to incorporate ESG issues in their valuations, thus forcing analysts to adopt them as well. This rising interest can be understood from a financial point of view as a way of managing risks and cost savings $(\mathrm{PwC}, 2012)$, which is also relevant for companies. This interest can also be considered from a fiduciary point of view, since the global financial crisis has shown that institutional investors were not effective stewards of their participants' interests (Butler \& Wong, 2011). Indeed, stakeholders hold pension funds accountable for the non-financial consequences of their investments (Sievänen et al., 2013).

Group pressures refer to initiatives undertaken by the members of the financial market to integrate ESG information in their investment decisions. There are initiatives promoting ESG integration led by schools or professional associations like the Association for Independent Corporate Sustainability and Responsibility Research (AI CSRR), which tend to shape the work models of the profession.

Financial analysts and investors have also created research centers such as the World Intellectual Capital Initiative (WICI) and the Investor Network on Climate Risk. These efforts have a positive impact on the members of financial markets, contributing to a better understanding of ESG issues, which reaches the market through training in ESG issues management.

However, according to Bassen and Kovacs (2008), the existence of so many initiatives results in a lack of coordination among them and an absence of projects encompassing all aspects of the issue. Even though the influence of these initiatives may be small at the intra-group level, it is much greater at the inter-group level, resulting in a me-too effect (Jemel-Fornetty et al., 2011).

Institutional pressures are forces exerted by non-members of the financial market. Two initiatives can be highlighted. On one hand, there are "light forces" like the voluntary adopted PRI, whose signatories are obliged to progressively incorporate ESG issues in their investment decisions. On the other hand, there are "strong forces" like regulation. These regulations include the European Accounts Modernization Directive 2003/51/EC and the regulation on reporting the use of ESG information by fund managers, although almost all European countries have adopted disclosure regulations for pension funds (Jemel-Fornetty et al., 2011; Knopf et al., 2010).

The important relationship between these drivers should be pointed out: regulation has led to the development of market forces, mainly for institutional investors, which in turn has forced analysts and asset managers to generate models and research teams to deal with ESG issues. Thus, the three drivers should not be studied separately as they are mutually reinforcing.

\subsection{Barriers}

The main barriers to ESG integration can be classified into: technical impediments, internal conventions and external conventions.

Technical impediments refer to the complexity and difficulty of managing ESG issues, especially measuring them. Obtaining a good measure for assessing ESG issues is constrained by available information (Igalens \& Gond, 2005), as the publication of information is often irrelevant and is distributed among a multitude of web pages and reports.

In order to be useful to financial markets, ESG information should be contrastable and comparable. Amaeshi (2010) calls for a singularization process to make ESG information calculable and quantifiable, a process that has just started. There are widespread initiatives dealing with ESG issues reporting like the Global Reporting Initiative (GRI) standard (Radley Yeldar et al., 2012) and the sustainability index, i.e. FTSE4Good and DowJones Sustainability.

With regard to conventions, the study by Guyatt (2006) is a landmark. She defines internal conventions as those conditions that are particular to an investment institution and the interactions that arise between individuals within an institution, while external conventions are conditions heavily influenced and determined by conventions that prevail at the market level and interactions between individuals in that setting.

Perhaps the most important internal convention is the segregated team approach. There are communication problems and lack of dialogue between companies' CSR departments, which usually deal with ESG information, asset managers and companies. On the other hand, companies' investor relations departments usually have no knowledge of what their CSR departments do. Thus, they are unable to respond to the interests of the members of the financial market and do not consider ESG issues to be linked to the company's strategy. In the end, the 
ESG specialists of each of the members of the financial market work in isolation, thus producing information that is not relevant for the other members of the market.

The short-term focus of the financial market affects both internal and external conventions, as shown by Juravle and Lewis (2008). From an internal perspective, investors are used to looking for quick returns on their investments. So, they hire managers specialized in financial issues and focus on analyzing the financial performance of the company in the short term. This makes analysts assess quarterly results. In the end, the whole market is affected, and what starts as an internal convention also becomes an external one.

A widespread belief in the financial market, and thus the external convention, is the supposed negative relationship between social and financial performance. Although a cause-effect relationship could be proven in the long-term (Perrini et al, 2012; Orlitzky, 2003), this does not coincide with the temporal horizon that analysts and asset managers work in. The root of this barrier is the belief of most investors that ESG integration does not add value, even though different works have counteracted this belief (Hoehler \& Hespenheide, 2013; Hespenheide \& Hoehler, 2012).

\section{Methodology and Sample}

Although different studies have analyzed how CSR is perceived by financial analysts and asset managers (Fieseler, 2011; Jaworsky, 2007), this study uses a novel approach consisting of interviews to analyze ESG integration in the Spanish financial market based on the opinion of its different members: investors, invested companies, asset managers and analysts. Similar to Williams and Schaefer (2012), a social-constructionist approach is applied to understand how the members of the Spanish financial market perceive and treat ESG integration.

Table 1. Sample information

$\underline{\text { Sample composition }}$

\begin{tabular}{|c|c|}
\hline Companies $(N=5)$ & Asset managers $(N=3)$ \\
\hline • Repsol (Oil industry) & - Kepler \\
\hline - Gamesa (Renewable energy industry) & - Santander \\
\hline - Sacyr y Vallehermoso (Construction and utilities industry) & • Hermes \\
\hline \multicolumn{2}{|l|}{ - Telefónica (Telecommunications industry) } \\
\hline \multicolumn{2}{|l|}{ • BBVA (Financial industry) } \\
\hline Analysts $(N=4)$ & Investors $(N=4)$ \\
\hline \multirow{2}{*}{ - Council on Ethics of the Norwegian Government Pension Fund Global } & - Public Administration \\
\hline & Occupational pension fund \\
\hline - Vigeo & - Cajasol occupational pension fund \\
\hline - SAM & - La Caixa occupational pension fund \\
\hline • Nomura & - AEMEC \\
\hline
\end{tabular}

$\underline{\text { Sample selection }}$

Companies

- To guarantee the diversity of companies, the 35 companies listed in the Spanish benchmark stock market index (IBEX-35) were analyzed following two factors: ownership structure (1) and business sector and main ESG impacts of this sector (2).

- As the companies were analyzed from the perspective of "invested companies", the person interviewed was from the investor relations department. In one case (Sacyr y Vallehermoso), the same person was responsible for both investor relations and CSR.

Investors

- In order to represent the diversity of investors and shareholders, three types of investors were studied: companies with relevant investment in other companies, institutional investors and shareholders. 
- Institutional investors are mainly pension funds, which have been the most involved in ESG integration.

- In order to obtain the opinion of a representative subsample of minority shareholders, the Spanish Association of Minority Shareholders (AEMEC) was interviewed. However, the interview revealed that its activities are focused on legal issues and have nothing to do with ESG integration.

Asset managers and analysts

- The study considered ESG analysts, financial analysts, and national and international asset managers.

Respondents were recruited according to their representativeness in the Spanish financial market. The final sample of sixteen respondents fulfilled the objective of a balanced distribution between national and international members with investing experience in Spanish financial markets. The sample was divided into four subsamples: investors, companies, asset managers and analysts. The subsample of investors was biased towards institutional investors, as they are the most active in SRI practices. The subsample of companies included companies from the main sectors of the Spanish economy and different kinds of ownership structure. Maximum diversity was sought within each of these subsamples. The composition and selection of the sample is shown in Table 1.

The main shortcoming of this study is the small sample size due to time and funding restrictions. Considering the scarcity of similar research in Spain, it is better to have imperfect evidence that could improve our understanding of the situation as opposed to no evidence at all (Abreu et al., 2005). However, further research using a larger sample size should be carried out to confirm the findings of this paper.

The methodology used for the analysis of ESG integration in the Spanish financial market was qualitative, as we used a semi-structured questionnaire that addressed the main aspects of ESG issues (see Table 2).

Table 2. Questionnaire information

\footnotetext{
Questionnaire design

First draft: The literature review used in the construction of the theoretical framework reveals the main concerns about ESG integration. The questions included in the questionnaire were formulated based on this literature review.

- First revision: The first draft was reviewed and commented on by academic experts on financial and ESG issues from five Spanish Universities.

Second draft: The comments of the first revision were taken into account; the questionnaire was modified accordingly to obtain the second draft.

- Second revision: The second draft was reviewed and commented on by professional experts on financial markets and ESG issues from different kinds of organizations, key informants and academic colleagues.

Final questionnaire: The comments of the second revision were taken into account; the questionnaire was modified accordingly to obtain the final questionnaire.

\section{Interviews of about an hour long}

- Workshop: A short version of the final questionnaire was elaborated after coding the interviews. This short version was answered by a selected group of 23 asset managers, investors and analysts to contrast and update the results obtained from the final questionnaire.
}

During the second half of 2011, interviews of around one hour long each were conducted. The semi-structured interviews explored how the participants of the Spanish financial market understand and manage ESG issues. All the interviews were digitally recorded and transcribed.

The interviews were analyzed following different literature on qualitative research, such as Bogner et al. (2009). This methodology allows the interviewer to direct the topic and present specific questions in the course of an interview if required (Yli-Pelkonen, 2008). Interviews were properly coded according to the theoretical framework. If the obtained answers were in agreement with the theoretical framework, the Spanish financial market was considered not to show any particularities. However, if they were not in agreement with the theoretical framework, the Spanish financial market was considered to show particularities. This way, a deeper understanding of ESG integration in the Spanish financial market is obtained.

The coded data were linked back to the literature reviewed, allowing the design of a short version of the final questionnaire which we administered to a selected group of 23 people at an SRI workshop held in the spring of 2013. The participants were mainly institutional investors (61\%), although there were also banks and asset 
managers, one ESG analyst international company and some SRI academic experts. Data obtained in the workshop were linked to the theoretical framework and contrasted with the results of the final questionnaire to validate results.

\section{Results}

\subsection{Drivers for ESG integration in Spain}

Table 3 summarizes the main findings of the study. Evidence supporting the identified drivers has been found, but interviewees also revealed factors restraining the role of the drivers. Further analysis of these drivers, supported by quotations from the interviewees, follows.

Table 3. ESG integration drivers in Spain

\begin{tabular}{ll}
\hline$\underline{\text { Market pressures }}$ \\
\hline$\times$ Role of institutional investors \\
$\checkmark$ Role of High Net Worth individuals \\
$\checkmark$ ESG issues for risk management and cost saving \\
$\checkmark$ ESG issues for fulfilment of fiduciary duties \\
$\underline{\text { Group pressures }}$ \\
$\times$ Initiatives by schools or professional associations \\
$\times$ Training for dealing with ESG issues \\
$\times$ Increasing awareness of ESG issues through the media \\
$\underline{\text { Institutional pressures }}$ \\
$\checkmark$ International organizations efforts \\
$\times$ Regulation \\
\hline
\end{tabular}

Note. $\checkmark$ Driver evidenced for the Spanish case; $\times$ Driver not evidenced for the Spanish case

\subsubsection{Market Pressures}

All interviewees agreed that pension funds play a key role in driving SRI in Spain. In recent years, these occupational pension funds have changed from a reactive attitude to scandals in the business environment to a proactive attitude requiring ESG integration. Institutional investors, mainly pension funds, compose $99 \%$ of Spanish SRI assets under management (Eurosif, 2010a); so they currently constitute the market for ESG integration.

Although progress has been made in pension funds in the last three years, ESG- related policies, decisions and actions are still at an early stage or do not exist at all in some funds. Spanish regulation of fiduciary duties of pension funds restrains the application of ESG criteria in investment decision-making, as reported by Richardson and Preu (2011) for the German case. When pension funds fully adopt ESG integration, a cascade effect may occur, spreading the consideration of ESG issues across the Spanish financial market.

A surprising finding is that companies agree that HNWIs are showing more and more interest in ESG integration. Thus, one company mentioned: "For financial issues, the relationship with the family office is handled by technical experts, but general meetings with the owner are also held, and random questions are addressed." But as another company says, this integration is partly due to their convictions and partly to profitability.

As pointed out by Eurosif (2010a), this has already occurred in some countries like the United Kingdom. Thus, the findings of EABIS (2009) on the important role of private banking in the momentum of ESG integration are confirmed for the Spanish case: HNWIs seek an investment that provides stable financial performance over time, although its performance may be lower.

Interviewees agree that ESG integration greatly contributes to reducing risks or at least to not losing profitability, as theorized by Bassen and Kovacs (2008) and Juravle and Lewis (2008). This is very important in pension funds, whose profit margins are generally low. The importance given to profitability could be seen as what Amaeshi (2010) calls logic of calculation and singularisation for profits, suggesting that profitability is a condition for ESG integration to be mainstreamed and establishes that ESG issues have to be treated according to their 
financial potential. As one investor said: “"Following ESG criteria to achieve better profitability...no, it is an error; I think it is an error."

Risk management makes firms look for both business opportunities and threats that foster innovation and create value for the company and the community, recognizing that ESG issues are a powerful tool for the internal management of the company. In this sense, one analyst pointed out: "There are factors of a company related to Sustainability [...]. What is an issue is that a company is able to understand its challenges and its opportunities, and how it is able to deal with them." Another analyst mentioned "There are companies who proactively question the analyst: And why do you do that? What is going on? What are my challenges? That helps them understand what we expect and what investors expect from them".

Nevertheless, analysts pointed out that the contribution of ESG integration to company assessment depends on its management cycle and the general business cycle. In fact, companies perceive that investors seek appropriate risk assessment rather than a triple bottom line approach. Analysts highlight that risk is not assessed according to current policies, but in response to previous events and results, which coincides with the opinion of some pension funds and evidences the reactive behavior of companies (Steger, 2012).

Companies agreed that the only existing demand for ESG integration today comes from pension funds and private banking. As Richardson and Preu (2011) pointed out for Germany, Spanish consumers do not demand SRI in the way it is now commercialized, and intermediaries do not offer products related to ESG issues because they do not see a potential benefit. Furthermore, the structure of the Spanish financial market has not helped to foster ESG integration (Lozano et al., 2006).

Finally, pension funds acknowledge that, while the market rewards environmental factors, social and labor factors are the most relevant for them, especially those related to human rights. This is due to the fiduciary duty of pension funds. In fact, they even call the latter exclusion factors: every company has to manage them.

\subsubsection{Group Pressures}

Despite the wide acceptance of most international standards related to SRI and CSR in Spain, there are few joint initiatives that combine Spanish financial market efforts. Commitments are usually made individually, either by companies, asset managers or occupational pension funds, evidencing the clear lack of a collective effort to promote ESG integration.

It is also noteworthy that ESG analysts claim to work independently and fairly isolated from other ESG analysts. A similar situation was observed by Jemel-Fornetty et al. (2011), who also found that ESG research units in companies are very independent and interact very little with other professionals in their field. Therefore, although the rise of a new area in a profession is usually reflected in the form of common interest, there are few coordinated initiatives regarding ESG issues in the Spanish financial market, excepting the Spanish Social Investment Forum (Spainsif) founded in 2009.

Interviewees also agreed that lack of education and training is one of the great obstacles to increasing sales related to ESG assets. In this sense, one investor remarked that financial culture is a problem in Spain and should be taught at the elementary and High School level. As one company pointed out: "There is an education problem; this is the main barrier to starting to train in ESG criteria". Financial products sales teams in Spain find it difficult to manage ESG issues, as they have been trained and are used to dealing with financial information, unlike in France, where teams are being trained in ESG criteria and SRI (Eurosif, 2010a).

Furthermore, most interviewees agreed that most retail investors are not interested in participating in the financial market, as pointed out by AEMEC. This lack of financial literacy does not occur only in Spain (Lusardi and Mitchelli, 2007). As Richardson and Preu (2011) evidenced for Germany, the interviewed pension funds and assets managers stated that retail investors in Spain do not practice active ownership. Spanish retail investors have a conservative profile and tend to prefer fixed income assets, seeking low-risk investments.

Another aspect highlighted by interviewees is the role of the press. Both companies and analysts stated that the treatment of news related to companies in terms of either ESG issues or financial factors is somewhat sensationalist (two examples are shown below). News is reported without thorough knowledge of the circumstances surrounding it: the importance of news depends more on advertising than on content. This way, information on ESG issues becomes a tool of disinformation unsuitable for decision-making.

"When investors get up in the morning and read their newspapers, they often make investment decisions based only on the front page headlines, and they give credit to things that are not true, or that are half-truths or incomplete truths. Fighting this is very complicated because the immediacy of the press will always be infinitely greater than one's own". Company 
"There are issues that have a lot of notoriety in the press, and there are other issues with a greater impact on the minority shareholder that have not even been mentioned." Investor.

\subsubsection{Institutional Pressures}

Most pension funds agree that the Principles for Responsible Investment (PRI) are a key element for ESG integration and highlight the amount of resources that they have been able to mobilize. However, despite the wider acceptance of PRI, they are not yet fully implemented in pension funds policies and management.

Another factor that has driven ESG integration is the development of regulations encouraging transparency based on the principle of "complain or explain". Over 10 years ago, countries where SRI assets under management are now sizeable, such as the United Kingdom and France, adopted regulations requiring pension funds to state whether or not they apply ESG criteria in selecting their portfolios (Knopf et al., 2010). Given the diversity of existing reporting standards, the interviewed companies perceive that ESG reporting needs to be regulated to catalyse and understand ESG information, which has just occurred in Spain. This is a call for the singularization of information claimed by Amaeshi (2010).

However, as one asset manager and analyst agree, countries provide different non-financial information because legislation in different countries results from different interests. Therefore, a common legislative basis should be established through the mediation of an institution.

Regulation concerning ESG integration has just been promulgated in Spain. The Ley 2/2011 de economía sostenible de 4 de marzo and the Ley 27/2011 de 1 de agosto, sobre actualización, adecuación y modernización del sistema de Seguridad Social made the reporting of ESG issues mandatory for companies and institutional investors, although its effect has not yet become evident. This explains the state of ESG integration in the Spanish financial market: since institutional investors, the main driver that pushes other members of the market, have not yet adopted ESG integration, neither have the other members of the market.

\subsection{Barriers for ESG Integration in Spain}

Table 4 shows the main barriers found in this study. As for drivers, evidence was found both supporting and rejecting previously established barriers. Further analysis of the barriers, supported by quotations from the interviewees, follows.

Table 4. ESG integration barriers

\begin{tabular}{ll}
\hline \multicolumn{1}{|c}{ Technical impediments } \\
\hline & $\checkmark$ No single accepted methodology to measure ESG issues \\
& $\checkmark$ No interconnection between financial and ESG information \\
& Internal conventions \\
& $\checkmark$ Segregated team approach \\
& $\checkmark$ Imbalanced hierarchy of team functions \\
& $\checkmark$ Focus on relative returns at investor meetings \\
& $\checkmark$ Generic criteria used for fund manager selection \\
& $\checkmark$ Generic criteria used for performance review \\
& External conventions \\
& $\checkmark$ Identification of short-term mispricings \\
& $\checkmark$ Focus on tangible financials \\
& $\checkmark$ Emphasis of engagement on near term share price drivers \\
& $\checkmark$ Active mandates geared towards relative returns \\
& $\checkmark$ Short-term performance review \\
\hline
\end{tabular}

Note. $\checkmark$ Barrier evidenced for the Spanish case; $\times$ Barrier not evidenced for the Spanish case. 


\subsubsection{Technical Barriers}

All interviewees agreed that much time, effort and money are needed to analyze ESG issues due to their complexity and uncertainty. This often forces companies to outsource expensive information services, as the interviewed pension funds do.

Specifically, analysts indicated that ESG issues can be very different depending on the sector and the country where the company operates. ESG issues become more complex in areas exposed to ESG risks and in regions whose culture is not easily understood. Companies and pension funds highlighted that this situation requires the assistance of third parties who know the culture.

A major difficulty is the lack of a global, universally accepted methodology for analyzing ESG issues and CSR to compare companies. Pensions funds doubt the materiality of the information reported according to GRI Guidelines, which has already been debated (Boiral, 2013; Moneva, 2006). Concerning sustainability indexes, companies recognized that they may be useful, but they have their limitations as Fowler and Hope (2007) pointed out. They are perceived as a kind of reputational ranking rather than evidence of good ESG management and performance.

Most indicators of ESG issues lack predictive potential. This is not a technical barrier for SRI development, but a deficiency of the indicators. Analysts stressed that when considering ESG integration, it is important to be ahead of the market, spotting emerging opportunities and threats, which are not always measured by available indicators.

The interviewed companies stated that they would gladly accept a legislative initiative with clear, well-defined objectives to provide a stable framework for reported information and allow inter-and intra-sector comparisons between companies. Investors have great difficulty managing this huge amount of ESG information, and there are few mechanisms to ensure its truthfulness. Companies and analysts also pointed out that the amount of available information makes the decision-making process extremely difficult.

Asset managers stressed that public information made available by companies does not allow them to identify trends in ESG issues, and they have to rely on specialized third parties. Even so, these topics tend to be financial strains which are very dynamic, uncontrollable and change in the short-term. In contrast, analysts think that companies are indeed transparent and report a great amount of information, although it may not allow them to make decisions. Thus, there is no clear connection between financial information and information on ESG issues.

\subsubsection{Internal and External Conventions}

This study found that communication and engagement between the different agents of the investment community is ineffective and is the main internal convention. There is a clear lack of dialogue between investor relations departments and CSR departments and little or no dialogue between investors and companies. When there is some communication, it is very poor and only initiated when the company has a problem known by the public. Spanish multinational companies are beginning to recognize the importance of dialogue and view it as an important collaborative tool. Investors highlighted that dialogue with foreign companies with no presence in Spain is inadequate or nearly non-existent due to different cultures, languages and distance. Nevertheless, some pension funds have been striving to overcome these problems and engage in more fluid dialogue in the last few years.

Some asset managers and analysts pointed out that this lack of interaction between investors and companies makes the role of financial intermediaries in investment activities crucial. This breaks the connection between supply and demand, while placing financial intermediaries in a powerful position (Guyatt, 2006). In Spain, as in Germany (Richardson and Pre, 2011), intermediaries are key to the financial market and they do not use ESG information. In some cases, dialogue between investors and companies lacks transparency. As one interviewee stated, potential conflicts between investors or asset managers and companies are sometimes solved in private conversations. Contrary to the close scrutiny of polemic situations in Anglo Saxon countries, this option is often preferred in continental countries.

One of the least developed channels of communication is that between pension funds and their asset managers. In most cases, pension funds allow the asset manager to operate freely on ESG issues, due to the lack of control channels. This situation would change if fund managers knew about ESG issues, but none of the interviewed fund managers knew how to manage ESG issues and relied on third parties.

Nevertheless, this is changing due to the concern of pension funds about including ESG issues in the fund's portfolio. Consequently, contact between asset managers and companies specialized in ESG issues is beginning 
to increase, providing them with tools to obtain better knowledge of the ESG impacts of the investments made for the fund. Furthermore, fund managers now recognize that basic knowledge on ESG issues is essential for successful ESG integration.

Interviewed pension funds clearly stated that their goal is to obtain an established profitability while addressing ESG issues due to imposed fiduciary duties. This can make funds accept lower profitability in exchange for better ESG performance, similar to what Richardson and Preu (2011) observed for Germany. These pension funds rely on the collaboration of people with knowledge of ESG issues (mainly trade union representatives), as well as outsourced external ESG services and resources.

The interviews of analysts revealed that they use a wide array of approaches to ESG integration. Some are specialized in ESG issues, while others only consider financial issues. Other analysts only consider ESG issues related to company performance or that contribute to a true and fair view of the invested companies.

The interviewed Spanish companies approach CSR from a strategic point of view, searching for business opportunities in social and environmental fields while reducing risks. Companies consider ESG criteria a useful tool for evaluating risks and improving the long-term performance of the company, as stated by EFFAS (2008). This evidences the conviction that managing ESG issues can be useful in improving a company's management, but financial issues remain the most important. In this sense, one company pointed out: "If you follow sustainability criteria, long-term performance will be affected. Perhaps it will be detrimental for today or tomorrow, but for long-term sustainability, this is what counts."

Some interviewed pension funds admitted that their asset managers had difficulties applying the ESG criteria defined by the fund to their investment decisions. Asset managers agreed and added that their employees find it difficult to understand and work with these concepts, as they do not know how to apply them to their investment decisions or what their performance will be. Other analysts only consider ESG criteria to be indicators of the reputational value of a company, which is also very difficult to include in traditional decision-making models due to its complexity and intangible nature.

However, some interviewed analysts and asset managers pointed out that many other agents do not agree that ESG integration adds value.

"Financial analysts do not believe in ESG criteria, I have heard many times "I need proof that this is profitable." "',

Although there are diverse opinions about the financial value added by the inclusion of ESG criteria in investment decisions, the prevailing view is that their inclusion does not ensure higher profits. Based on previous experience, some pension funds, analysts and companies consider that the relationship between ESG issues and profitability is positive. Others are sceptical, as they consider that ESG issues can have a positive impact on risk reduction but not on financial performance. All interviewees generally agreed on the importance of the materiality of information.

Financial markets have traditionally perceived ESG issues as an external imposition, as they did not originate in financial markets. Nevertheless, all the interviewees agreed that ESG criteria could be successfully implemented in financial products as long as investors and clients insist they be included.

In spite of the marginal inclusion of ESG criteria in investment decisions, interviewees perceive a change in some institutional investors in the last few years. They are including more sustainability factors in their investment decisions and look for long-term investments.

Nevertheless, they all agreed that retail investors mainly invest from a short-term perspective, seeking the best dividend with the exception of some HNWIs (Jemel-Fornetty et al., 2011).

\section{Concluding Remarks}

Market pressure and especially institutional pressure are the main drivers of SRI in Spain, but many challenges still remain. ESG integration in pension funds and other institutional investors is one of the key drivers leading analysts and asset managers to incorporate ESG criteria in their investment recommendations and decisions. However, the momentum of occupational pension funds has come to Spain later than to other countries. Although the Spanish SRI market has evolved positively in recent years in terms of asset size (Albareda et al., 2010), changes have not yet been made in the modus operandi of pension funds according to ESG criteria.

At the individual level, the interviewees believe that ESG integration has advantages, but it is not applied in the financial market. ESG issues are viewed by the members of the financial market as a stake for better risk assessment and a tool for detecting opportunities and threats, while the market has not yet taken them into 
account, resulting in the autonomy of groups belief (Orléans, 2004). If a member of the financial market starts to use ESG information, that member will soon find that his behavior is not in accordance with current financial market trends and will finally not use it. If ESG information is to become mainstreamed, the members of the financial market must believe that all members of the financial market value ESG information. Several initiatives, like UNPRI, are trying to increase this market awareness.

The lack of regulation regarding ESG transparency has also been a clear barrier in Spain, unlike in the United Kingdom and France where regulation was promulgated years ago. Self-regulatory initiatives, such as UNPRI, have recently made important advances, fostering the development of communication channels between different agents. Thus, there has been a change in attitude towards dialogue or engagement in Spain, and we can conclude that this change is driving the interest in managing ESG issues.

Concerning group pressure, there are few joint initiatives concerning ESG integration in Spain. CSR teams work independently and isolated from other CSR or financial teams, and there is a clear lack of financial literacy and training in ESG criteria. This can be explained by strong market competition and little effort to manage ESG issues, as well as by the lack of a "push effect" like the one coming from institutional investors through regulation.

All the established barriers are confirmed in this study. Investors and companies did not agree on key or material aspects. Interviewees felt that ESG issues should be incorporated in discounted cash flows for company valuation, and therefore they urged us to demonstrate the exact relationship between ESG and financial performance. As some analysts and asset managers pointed out, SRI will only experience a significant increase if ESG criteria are shown not to greatly undermine or boost financial performance.

In accordance with other studies (Jarowski, 2007; Juravle \& Lewis, 2008), the major barriers to the integration of ESG criteria in investment decisions are the huge amount of resources needed to obtain homogeneous and consistent ESG information and the difficulty of obtaining and managing it.

In agreement with Jemel-Fornetty et al. (2007), we conclude that these technical barriers are just a rationalization or justification. The main reason why ESG issues are not integrated in the mainstream is the problem of conventions, especially external conventions: the greater the uncertainty in an area, the greater the influence of conventions as a coordination and group formation mechanism. These conventions can be modified through a process of institutionalization. This study did not analyze the role of institutionalization in slowing external conventions. However, we are aware that this is a very interesting topic that should certainly be addressed in future research.

Retail investors' lack of interest in SRI products can be explained by two facts. Intermediaries who play a key role in the financial market are not trained in the use of ESG criteria, and Spanish consumers and retail investors have little financial literacy. They do not know what SRI is and do not demand it. The Netherlands is a good example of how a measure regarding intermediaries can boost SRI, and thus the use of ESG criteria.

As to similarities between Spain and the leading SRI countries, evidence supports that the Spanish case is similar to the German case. Both countries have experienced small growth in the volume of assets managed according to ESG integration in the last 6 years (Eurosif, 2010a), partly due to the conservative profile of investors, financial intermediaries not promoting SRI and the lack of regulation. The deficiencies in the use of environmental, social and governance information in investment decision-making in Spain have been identified. Now it is time to solve them.

\section{References}

Abreu, R., David, F., \& Crowther, D. (2005). Corporate social responsibility in Portugal: empirical evidence of corporate behaviour. Corporate Governance, 5(5), 3-18. http://dx.doi.org/10.1108/14720700510630013

Amaeshi, K. (2010). Different Markets for Different Folks: Exploring the Challenges of Mainstreaming Responsible Investement Practices. Journal of Business Ethics, 92(1), 41-56. http://dx.doi.org/10.1007/s10551-010-0633-8

Bassen, A., \& Kovacs, M. (2008). Environmental, Social and Governance Key Performance Indicators from a Capital Market Perspective. ZeitschriftfürWirtschafts- und Unternehmensethik, 9(2), 182-192.

Bogner, A., Littig, B., \& Menz, W. (2009). Interviewing experts. New York: Palgrave Macmillan.

Boiral, O. (2013). Sustainability reports as simulacra? A counter-account of A and A+ GRI reports. Accounting, Auditing \& Accountability Journal, 26(7), 1036-1071. http://dx.doi.org/10.1108/AAAJ-04-2012-00998 
Butler, S., \& Wong, S. (2011). Recent trends in institutional investor responsibilities and stewardship. Pensions, 16(1), 80-85. http://dx.doi.org/10.1057/pm.2011.4

Capelle-Blancard, G., \& Monjon, S. (2012). Trends in the literature on socially responsible investment: looking for the keys under the lamppost. Business Ethics: A European Review, 21(3), 239-250. http://dx.doi.org/10.1111/j.1467-8608.2012.01658.x

Crifo, P., \& Forget, V. D. (2013). Think Global, Invest Responsible: Why the Private Equity Industry Goes Green. Journal of Business Ethics, 116(1), 21-48. http://dx.doi.org/10.1007/s10551-012-1443-y

De la Cuesta, M., Muñoz, M. J., \& Fernández, M. A. (2006). The analysis of social performance in the Spanish financial industry through public data: A proposal. Journal of Business Ethics, 69(3), 289-304. http://dx.doi.org/10.1007/s10551-006-9091-8

EABIS. (2009). Corporate Responsibility, Market Valuation and Measuring the Financial and Non-Financial Performance of the Firm. European Academy for Business in Society.

EFFAS. (2008). KPIs for ESG.A Guideline for the Integration of ESG into European Society of Financial Analysts Societies Financial Analysis and Corporate Valuation. European Federation of Financial Analysts Societies.

Escrig-Olmedo, E., Muñoz-Torres, M. J., \& Fernández-Izquierdo, M. A. (2013). Sustainable Development and the Financial System: Society's Perceptions About Socially Responsible Investing. Business Strategy and the Environment, 22(6), 410-428. http://dx.doi.org/10.1002/bse.1755

Eurosif. (2010a). European SRI Study 2010. Amundi, BNP Paribas, Cheuvreux and Edmon de Rothschild report.

Eurosif. (2010b). High Net Worth Individuals \& Sustainable Investment 2010. Eurosif.

Eurosif. (2011). Corporate Pension Funds and Sustainable Investment Study. European Social Investment Forum.

Eurosif. (2012). European SRI Study 2012. Amundi, Axa, Nordea and Pictec.

Fieseler, C. (2011). On the corporate social responsibility perceptions of equity analysts. Business Ethics: A European Review, 20(2), 131-147. http://dx.doi.org/10.1111/j.1467-8608.2011.01616.x

Fowler, S. J., \& Hope, C. (2007). A Critical Review of Sustainable Business Indices and their Impact. Journal of Business Ethics, 76(2), 243-252. http://dx.doi.org/10.1007/s10551-007-9590-2

Freshfields Bruckhaus Deringer. (2005). A Legal Frame-work for the Integration of Environmental, Social and Governance Issues into Institutional Investment. Report produced for the Asset Management Working Group of the UNEP Finance Initiative.

Guyatt, D. J. (2006). Identifying and Overcoming Behavioural Impediments to Long Term Responsible Investments-a Focus on United Kingdom Institutional Investors. PhD Thesis, University of Bath (United Kingdom).

Hespenheide, E. J., \& Hoehler, D. A. (2012). Drivers of Long-Term Business Value Stakeholders, stats, and strategy. Deloitte.

Hoehler, D. A., \& Hespenheide, E. J. (2013). Finding the Value in Environmental, Social and Governance Performance. Deloitte Review (Complimentary article reprint), 12(2), 99-111.

Igalens, J., \& Gond, J. P. (2005). Measuring Corporate Social Performance in France: A Critical and Empirical Analysis of ARESE Data. Journal of Business Ethics, 56(2), 131-148. http://dx.doi.org/10.1007/s10551-004-3529-7

Jaworski, W. (2007). Use of Extra-Financial information by research analysts and investment managers. European Center for Corporate Engagement.

Jemel-Fornetty, H., Louche, C., \& Bourghelle, D. (2011). Changing the Dominant Convention: The Role of Emerging Initiatives in Mainstreaming ESG.

Juravle, C., \& Lewis, A. (2008). Identifying impediments to SRI in Europe: a review of the practitioner and academic literature. Business Ethics: A European Review, 17(3), 285-310. http://dx.doi.org/10.1111/j.1467-8608.2008.00536.x

Knopf, J., Kahlenborn, W., Hajduk, T., Weiss, D., Feil, M., Fiedler, R., \& Klein, J. (2010). National Public Policies in the European Union. Luxembourg: Publications Office of the European Union. 
Louche, C., \& Pérez, R. (nd.). Finance and Sustainability Towards a New Paradigm? A Post-crisis Agenda (pp. 85-117). Emerald Group Publishing Limited.

Lozano, J. M., Albareda, L., \& Balaguer, M. R. (2006). Socially Responsible Investment in the Spanish financial market. Journal of Business Ethics, 69(3), 305-316. http://dx.doi.org/10.1007/s10551-006-9092-7

Lusardi, A., \& Mitchelli, O. (2007). Financial Literacy and Retirement Preparedness: Evidence and Implications for Financial Education. Business Economics, 41(1), 35-44. http://dx.doi.org/10.2145/20070104

Moneva, J. M., Archel., P., \& Correa, C. (2006). GRI and the camouflaging of corporate unsustainability. Accounting Forum, 30(2), 121-137. http://dx.doi.org/10.1016/j.accfor.2006.02.001

Novethic. (2012). ESG Strategies of Asset Owners. Different Scenarios across Europe. Novethic, France.

Orléan, A. (2004). What is a Collective Belief? In P. Bourgine, \& J. P. Nadal (Eds.), Cognitive Economics (pp. 199-212). New York: Springer-Verlag.

Orlitzky, O., Schmidt, F. L., \& Rynes, S. L. (2003). Corporate Social and Financial Performance: A Meta-analysis. Organization Studies, 24(3), 403-441. http://dx.doi.org/10.1177/0170840603024003910

Perrini, F., Russo, A. A., Tencati, A., \& Vurro, C. (2012). Deconstructing the Relationship Between Corporate Social and Financial Performance. Journal of Business Ethics, 102(1), 59-76. http://dx.doi.org/10.1007/s10551-011-1194-1

Prado-Lorenzo, J. M., Gallego-Álvarez, I., García-Sánchez, I. M., \& Rodríguez-Domínguez, L. (2008). Social responsibility in Spain: Practices and motivations in firms. Management Decision, 46(8), 1247-1271. http://dx.doi.org/10.1108/00251740810901417

$\mathrm{Pw}$, C. (2012). Responsible investment: creating value from environmental, social and governance issues. Price water house Coopers Report.

Radley, Y. (2012). The value of extrafinancial disclosure What investors and analysts said. Radley Yeldar, Accounting for Sustainability and Global Reporting Initiative.

Richardson, B. J., \& Preu, F. J. (2011). German Socially Responsible Investment: Barriers and Opportunities. German Law Journal, 12(3), 865-900.

Sandberg, J., Juravle, C., Hedesström, T. M., \& Hamilton, I. (2009). The Heterogeneity of Socially Responsible Investment. Journal of Business Ethics, 87(4), 519-533. http://dx.doi.org/10.1007/s10551-008-9956-0

Sievänen, R., Hannu, R., \& Scholtens, B. (2013). The Drivers of Responsible Investment: The Case of European Pension Funds. Journal of Business Ethics, 117(1), 137-151. http://dx.doi.org/10.1007/s10551-012-1514-0

Slager, C. H. (2012). Calculative Routines and Dynamic Reactivity: How an SRI Index Shapes CSR Practices. Academy of Management Best Paper Proceedings (forthcoming).

Sparkes, R., \& Cowton, C. J. (2004). The Maturing of Socially Responsible Investment: A Review of the Developing Link with Corporate Social Responsibility. Journal of Business Ethics, 52(1), 45-57. http://dx.doi.org/10.1023/B:BUSI.0000033106.43260.99

UNEP FI and WBCSD. (2010). Translating ESG into sustainable business value, Key insights for companies and investors. United Nations Environment Programme Finance Initiative and World Business Council for Sustainable Development.

Williams, S., \& Schaefer, A. (2012). Small and medium sized enterprises and sustainability: managers' values and engagement with environmental and climate change issues. Business Strategy and the Environment, 22(3), 173-186. http://dx.doi.org/10.1002/bse.1740

Yli-Pelkonen, V. (2008). Ecological information in the politic decision making of urban land-use planning. Journal of Environmental Planning and Management, 51(3), 345-362. http://dx.doi.org/10.1080/09640560801977224

\section{Copyrights}

Copyright for this article is retained by the author(s), with first publication rights granted to the journal.

This is an open-access article distributed under the terms and conditions of the Creative Commons Attribution license (http://creativecommons.org/licenses/by/3.0/). 